\title{
ФАЛЬКЛАРЫСТЫКА
}

\author{
Іна Швед \\ Брэст
}

\section{Гідралагічны код беларускага фальклору ${ }^{1}$}

\section{Уводзіны}

Шматлікія даследаванні у сферы сувязяў традыцыйнай і сучаснай культур грунтуюцца на ўсведамленні таго, што апрадмечаныя формы самабытнага духойнага вопыту мінулага, часткова захаваўшы сваю арыгінальную існасць, а часткова "пераапрадмеціўшыся", становяцца грунтам новых сінтэзаў, і гэтым падтрымліваюць духойны патэнцыял культуры. Архаічныя ў сваёй аснове сімвалы і коды, рэтранслюючы ператвораны ў каштоўнасныя ідэалы сацыяльна-культурны вопыт, прад'яўляюць кожнаму пакаленню імператывы дзейнасці, спосабы асэнсавання, узнаўлення рэчаіснасці, крытэрыі яе ацэнкі (сенсорнай, субліміраванай, рацыяналістычнай). I такім чынам уздзейнічаюць на сучаснае і будучае гэтай рэчаіснасці. Адсюль - абвастрэнне навуковай і грамадскай цікавасці да механізмаў і сродкаў (разгалінаванай сістэмы кодаў) мадэліравання і рэтрансляцыі жыццёва важных, правераных часам сэнсаў і самабытных формаў беларускай традыцыйнай культуры.

Неабходнасць вывучэння і захавання духойных набыткаў нашых продкаў, нераспрацаванасць шырокага кола праблем знакавай арганізацыі свету, адным з галоўных інструментаў якой выступае гідрала-

1 Праца выканана $\ddot{\mathrm{y}}$ межах тэмы "Структурна-тыпалагічныя параметры кодаў міфапаэтычнай карціны свету беларусаў (паводле фальклорных запісаў XIX-пач. XXI ст.)" задання 1.4.07 ДПНД "Гісторыя, культура, грамадства, дзяржава" на 2011-2015 гг., № дзяржрэгістрацыі 20140200 ад 14.03.2014. 
гічны код, накапленне адпаведнага багатага фактычнага матэрыялу, які чакае грунтойнага сістэмнага вывучэння паводле новых напрацовак у галіне фалькларыстыкі, семіётыкі, этналінгвістыкі, культуралогіі і іншых гуманітарных навук, добрая захаванасць архаічных гідралагічных вобразаў і жывучасць звязаных з імі міфапаэтычных уяўленняў (што выразна адбілася ў розных відах мастацтва), неабходнасць паглыблення разумення агульнаславянскага пласта ўяўленняў пра розныя аспекты светабудовы, зафіксаваных у гідралагічным кодзе, вызначаюць актуальнасць тэмы прапанаванага артыкула.

\section{Тэарэтыка-метадалагічныя аснаванні даследавання гідралагічнана кода, яго структурна-тыпалагічныя параметры і сувязі з сумежнымі кодамі}

Код - гэта сістэма абазначэнняў для перадачы, апрацоўкі і захавання інфармацы у у форме канцэптуальных утварэнняў, корпус аднатыпных знакаў, які мае сваю парадыгматыку і сінтагматыку. Кожны код вызначаецца ўласнай сістэмай рэлевантных прыкмет, якія выяўляюцца $\breve{y}$ наборы і суадносінах адзінак гэтага кода. Адзін з вызначальных чыннікаў семіясферы беларускага фальклору - гідралагічны код трактуецца намі як інструмент традыцыйнага мадэліравання свету на аснове яго пазнання, ацэнкі і апісання праз розныя семіятызаваныя віды водаў гідрасферы (акіян, мора, рака, возера, балота i падземныя воды, у першую чаргу такія іх выхады на зямную паверхню, як калодзеж, крыніца). Кожная з гэтых семіятызаваных міфапаэтычным мысленнем рэалій функцыянуе у беларускім фальклоры як сімвал - адмысловы вобраз, які з'яўляецца вынікам і ідэальнай формай прадметна-пачуццёвага, цэласнага, эмацыянальнага адлюстравання прадметай і з'яў матэрыяльнага свету.

Хоць надраднай катэгорыяй адносна ўсіх пералічаных чыннікаў гідралагічнага кода з'яўляецца вада, сама яна як такая (празрыстая бясколерная вадкасць, рэчыва, якое семіятызуецца міфапаэтычным мысленнем паводле разнастайных прыкмет, надзяляецца пэўнымі магічнымі функцыямі, выкарыстойваецца у розных рытуальных практыках і пад.) уваходзіць у іншы код - рэчываў, стыхій і прыродных з'яў, надрадным кодам якога з'яўляецца субстантыўны. (Гідралогія таксама вывучае не ваду як такую (фізічнае рэчыва ці хімічнае злучэнне), а пашырэнне і рэжым прыродных водаў на Зямлі, усе віды водаў гідрасферы ў акіянах, марах, рэках, вадасховішчах, балотах, падземныя 
воды). Калі сімволіка, семантыка, прагматыка чыннікаў гідралагічнага кода даследуецца ў сувязі з семіятызацыяй міфапаэтычным мысленнем абменных працэсаў паміж воднай паверхняй і слаямі атмасферы, можна гаварыць пра гідраметэаралагічны код з такімі яго элементамі, як дождж, снег, іней, раса, хмара, град і пад. Але такая класіфікацыя кодаў немэтазгодная, бо выклікае шэраг праблем, асабліва калі прадугледжваецца сістэмны аналіз кода. Усё яшчэ больш ускладняецца, калі прадметам даследавання становіцца метэаралагічная магія, у прыватнасці грунтойна даследаванае $\ddot{y}$ айчыннай і замежнай навуцы выкліканне дажджу на Беларусі ${ }^{2}$. Светапогляднай асновай магічнага выклікання дажджу з'яўляюцца ўяўленні пра сувязь зямных і нябесных водаў, але на першы план у гэтым выпадку выводзяцца магічныя маніпуляцыі з рознымі рэаліямі, акцыянальны код. Што да крыніц, калодзежаў, то яны ў якасці выхадаў вады з цвердзі падземнай на зямную паверхню уяўляліся найлепшым месиам для ўздзеяння на воды цвердзі нябеснай. Назва (і змест) артыкула аўтарытэтнага даследчыка метэаралагічнага кода М. Антропава "Белорусские этнолингвистические этюды: 2. Вызывание дождя (акциональный код)" (Язык культуры: семантика и грамматика, М., 2004) гаворыць сама за сябе.

Рэалізацыя сістэмнага падыходу да вывучэння кода немагчымая без ідэнтыфікацыі неабходнага і дастатковага комплексу характарыстык (якія ў сукупнасці вызначаюць існаванне кода як цэласнага феномена) і рэканструкцыі працэсу і вынікаў семантызацыі адпаведных аб'ектаў. Сярод прынцыпаў такога падыходу - вывучэнне не ізаляваных сімвалаў, а іх сукупнасці (акрэсленай сістэмы адносін), якая і ўтварае код, прычым цэласнасць тут - вызначальная ўласцівасць; сінтэз тэарэтычных (гісторыка-генетычных і функцыянальна-семантычных) уяўленняў пра код; вылучэнне фактараў, якія надаюць коду ўстойлівасць; акцэнт на сэнсе уззаемасувязі аднатыпных складнікаў-сімвалаў.

Пры вырашэнні задач, звязаных з сістэмным аналізам пэўнага кода, яго гісторыка-генетычнае даследаванне павінна дапаўняцца функцыянальна-семантычным. Як паказалі праведзеныя намі даследаван-

2 Гл., прыкладам: С. М. Толстая, Н. И. Толстой, Вызывание дождя в Полесье, (в:) Очерки славянского язычества, Москва 2003, с. 89-125; Л. Дучыц, Э. Зайкойскі, У. Лобач, Дождж, (у:) Міфалогія беларусаў. Энцыклапедычны слоўнік, Мінск 2011, с. 154-155; шэраг прац М. П. Антропава па праблеме метэаралагічнай магіі беларусаў і яе кодаў, у прыватнасці Кодовая структура белорусских обрядов и ритуалов, связанньх с вызьъванием дождя, "Etnolingwistyka. Problemy języka i kultury", t. 16, Lublin 2004; інш. 
ні дэндралагічнага, прыродна-ландшафтнага, колеравага і іншых кодаў, прадуктыўным з'яўляецца выкарыстанне функцыянальна-семантычнага, структурна-тыпалагічнага і параўнальна-гістарычнага метадаў. Прымяненне функцыянальна-семантычнага метаду дае магчымасць высветліць, што іменна ў генезісе кода абумоўлена пазафальклорнымі сувязямі і як гэтыя сувязі прадстаўлены $\ddot{y}$ ім, а таксама ўстанавіць месца кода $\ddot{y}$ традыцыйнай мадэлі свету (шырэй - культуры). Структурна-тыпалагічны метад дазваляе раскрыць механізмы ўпарадкавання семантычных сувязяў кожнага з сімвалаў, якія складаюць код, і інтэрпрэтаваць гэтыя сімвалы, прадставіӱшы іх у межах цэласнага ўтварэння, што функцыянуе разам з іншымі кодамі. Пры дапамозе параўнальна-гістарычнага метаду магчымае высвятленне генезісу кода, вызначэнне паралеляў вывучаемай з'явы у розных маштабах.

Правесці такое даследаванне штучна сканструяванага гідраметэаралагічнага кода (патрабаванне аднатыпнасці ў дачыненні да чыннікаў такога кода не вытрымліваецца), па меншай меры на сучасным узроўні фалькларыстычай навукі і $\ddot{y}$ межах аднаго, нават манаграфічнага даследавання, не ўяўляецца магчымым. Па-першае, "слоўнікі" той "мовы рэальнасці", якую выкарыстойвае традыцыя ў семіятычных мэтах у адносінах да кодаў гідралагічнага і метэаралагічнага, хоць і маюць зоны перасячэння, але адрозныя: вецер, віхор, маланка, мароз і пад. - найважнейшыя чыннікі кода метэаралагічнага, але не гідралагічнага ці гідраметэаралагічнага. Аднак менавіта з імі семіятызаваныя міфапаэтычным мысленнем дождж, снег, іней, раса, хмара, град з'яўляюцца аднатыпнымі сімваламі, складаюць цэласнае ўтварэнне, упарадкойваюць паводле аднаго механізму свае як унутраныя, так і знешнія семантычныя сувязі. Маленні, абыходы, аранне (дарогі, русла ракі), укопванне, агароджванне, выліванне, абліванне, біццё, размешванне (вады), галашэнне па тапельцу ля калодзежа і г.д. складаюць рытуальны комплекс выклікання даджу, утвараюць яго акцыянальны код, але ніяк не могуць лічыцца аднатыпнымі сімваламі з чыннікамі кодаў гідралагічнага і/ці метэаралагічнага. Пазафальклорныя сувязі, якімі абумоўлены генезіс гідралагічнага, метэаралагічнага і тым больш акцыянальнага кодаў, прадстаўленасць гэтых сувязяў у названых кодах, месца кодаў у жанравай сістэме фальклору, традыцыйнай мадэлі свету адрозныя. Чыннікі гэтых трох кодаў утвараюць адметныя і сінанімічныя (з агульнай семантыкай і матывіроўкай), і ізафункцыянальныя (з агульнай прагматыкай) рады сімвалаў, характар вар’іравання якіх таксама не супадае. Адпаведна гідралагічны, метэа- 
ралагічны, акцыянальны коды і іх чыннікі выяўляюць розныя сувязі з іншымі кодамі, у прыватнасці з такім вызначальным кодам культуры, як прасторавы. Гідралагічны код "на поўных правах" можа лічыцца сегментам ландшафтнага кода, які, у сваю чаргу, з'яўляецца адным з вызначальных чыннікаў кода прасторавага. Прасторавы ж код можна трактаваць як надрадную катэгорыю ў адносінах да кодаў гідралагічнага і ландшафтнага (прастора ў міфапаэтычнай карціне свету - гэта найперш сфера размяшчэння элементай ландшафту; увогуле прастора не можа быць апісана інакш, чым як шэраг пэўных аб'ектаў), але не $\breve{y}$ дачыненні кодаў метэаралагічнага ці рэчываў, стыхій або акцыянальнага. Прыкладам, у загадцы пра лодку паверхня вады трактуецца як прастора кшталту нябеснай, як локус, дарога, а дно вадаёма асацыюецца $з$ іншасветам, пры гэтым адлюстравальная ўласцівасць вады захоўвае важнае значэнне: Еду па раўнядзі, ад смериі на трь nядзі $i$ пад нагамі неба. Хоць сімволіка гідрааб'ектаў пэўным чынам звязана з сімволікай уласна вады і ўяўленні пра лучнасць нябеснай вільгаці з зямнымі водамі шырока прадстаўлены ў метэаралагічнай магіi, але гэта галіна народнай касмалогіi, якая павінна спецыяльна даследавацца з выкарыстаннем адпаведных метадалогіi і факталогіi. Ваду як субстанцыю (у прыватнасці, сродак магіi), дождж, снег, іней, метэаралагічную магію і г.д., такім чынам, алагічна ўключаць у разгледжаную іерархію кодаў: прасторавы - ландшафтны - гідралагічны.

У залежнасці ад маштабу члянення кодаў на элементы, можна вылучаць адметныя сінхронна-тыпалагічныя классы (тыпы) гэтых элементаў і адпаведна іx аналізаваць, у прыватнасці гідралагічны код уключае: семіятызаваныя 1) прыродныя, 2) "рукатворныя" гідрааб'екты. Ад задач і вынікаў кампанентнага аналізу названых тыпаў залежыць выгляд класіфікацыйнай мадэлі гідралагічнага кода. Так, яго сістэмаўтваральнымі элементамі з'яўляюцца названыя вышэй, па-першае, акіян, мора, рака, возера, балота, крыніца, па-другое, калодзеж. Для рэалізацыі сістэмнага падыходу да вывучэння гідралагічнага кода беларускага фальклору дастаткова даследавання ўсіх вызначаных сімвалаў паводле пералічаных вышэй прынцыпаў з выкарыстаннем апісаных метадаў. Між тым, карысным з'яўляецца і накладванне больш дробнай сеткі пры кампанентным аналізе кода. Так, могуць вылучацца і інтэрпрэтавацца ў аспекце адзначаных вышэй сувязяў такія чыннікі кода, як мора (канкрэтнае), мора-акіян, рэкі ("Балвань", "Буг", "Вялля (Вілія)", "Дзвіна", "Прыпяць", "Сож", "Днепр", "Дунай", "Нёман", "Міртвіца", "Свяціца", "Сула", "Уса", "Уздзянка", "Шчара", "Мухавец", "Прыпяць"; інш.), азёры ("Нарач", 
"Свіцязь", "Святое", "Стралкоўскае", "Князь-возера", "Жыд-возера", "Ольжанка", "Акно", "Чартова", "Дзедава", "Паганік", "Чорнае", "Белае"; інш.), балоты (іх канкрэтныя вобразы), крыніцы ("святыя", “чортавы", “богавы", "Пяцінка", "Янава", "Добрая Вада", "Дзявіччы калодзеж", "Грамячы калодзеж", "Магдалена"; інш.), стаў, копанка, брод, суток, вір, пэӱныя “міфічныя” гідрааб'екты і г.д. Гэты рад, бясспрэчна, можна працягваць. I паколькі гідралагічныя сімвалы з'яўляюцца міжжанравымі, то іх разгляд неабходна праводзіць на матэрыяле ўсіх асноўных жанрай і відаў фальклору, натуральна, $з$ улікам адметнасцяў. Паколькі гідралагічныя сімвалы - "вынік супрацоўніцтва" мастацкіх і немастацкіх утварэнняў у праекцыі істотных, стэрэатыпных уяўленняў пра гідрааб'екты, навуковае апісанне гэтых сімвалаў прадугледжвае вызначэнне іх кагнітыўнага зместу, зварот да адметных канцэпцый карціны свету і мадэлі свету.

3 прычыны таго, што гідралагічны код з'яўляецца падкодам ландшафтнага (ці прыродна-ландшафтнага, бо толькі калодзеж - "рукатворнае" збудаванне, ды і яно ў сваёй аснове мае выхад прыродных падземных водай), тэарэтыка-метадалагічныя падыходы да сістэмнага даследавання гэтых кодаў будуць адзінымі. Раскрыццю сутнасці адпаведных падыходаў і катэгарыяльнага апарату прысвечаныя нашы спецыяльныя працы, што пазбаўляе неабходнасці спыняцца на гэтым пытанні дадаткова ${ }^{3}$.

\section{Некаторыя вынікі даледавання гідралагічнага кода беларускага фальклору}

Адзначым толькі асноўныя моманты, якія датычаць рэканструкцы гідралагічнага кода беларускага фальклору і ўкажам на тое, што надзяленне гідрааб'ектаў высокім семіятычным статусам і іх шанаванне, паводле агульнага прызнання як айчынных, так і замежных вучоных (А. Беразовіч, Т. Валодзінай, Л. Вінаградавай, Т. Гамкрэлідзэ,

3 І. Швед, Усталяванне семантычных сувязей прыродна-ландшафтных сімвалаў беларускага традыџыйнага фальклору, "Весці НАН Беларусі. Серыя гуманітарных навук" 2011, № 1, с. 75-76; І. Швед, Тэарэтыка-метадалагічныя асновы сістэмнага даследавання прыродна-ландшафтнага кода міфапаэтычнага мыслення, "Веснік Палескага дзяржаўнага універсітэта. Сер. грамадскіх і гуманітарных навук" 2011, № 2, с. 57-61; І. Швед, Прыродна-ландшафтны код міфапаэтычнага мьслення як аб'ект міждысиыллінарнага даследавання, "Вучоныя запіскі БрДУ. Гуманітарныя і грамадскія навукі" 2011, вып. 7, ч. 1, с. 184-194. 
Л. Дучыц, Э. Зайкоўскага, Вяч. Іванава, У. Лобача, А. Ненадаўца, А. Панчанкі, Т. Шамякінай, І. Швед і інш.), - шырока вядомая і даволі старажытная з'ява ў культурах славян і іншых народаў свету. Адпаведна, факталагічны матэрыял даследавання настолькі шырокі, што яго апісанне як у дыяхраніі, так і сінхраніі павінна было б ахапіць усе навукова аўтарытэтныя публікацыі беларускага фальклору (у шырокім значэнні) і архіўныя, палявыя матэрыялы, бо, як адзначалася вышэй, гідрааб'екты выступаюць частотнымі міжжанравымі сімваламі беларускага фальклору.

Многія аспекты міфапаэтычных уяўленняў беларусаў пра ваду, гідрааб'екты у сувязі з семіятызацыяй прасторы міфапаэтычным мысленнем характарызуюцца даволі высокай ступенню вывучанасці (работы Э. Зайкоўскага, У. Лобача, А. Прохарава, С. Санько, М. Талстога, С. Талстой, І. Чароты; інш.). Так, у даследаваннях У. Лобача ${ }^{4}$ разглядаецца кола пытанняў пра новыя прынцыпы этналагічнага вывучэння семантыкі і сімволікі ландшафтных, у тым ліку гідралагічных, аб'ектаў, фактаў міфалагічнага асэнсавання дыялектных формаў вераванняў, звязаных $з$ імі. Даследчык вывучае крыніцы, азёры, балоты як значныя канкрэтна-рэчавыя элементы сакральнай геаграфіi беларускага Падзвіння. Пры гэтым аб'екты сакральнай геаграфіi трактуюцца У. Лобачам як элементы прыроднага ландшафту, якія ў калектыўнай фальклорнай памячі суадносячиа з іншасветам $i$ яго прадстайнікамі $i$ ў іх міфалагічнай праекиыі выразна супрачьпастайляючиа сферы прафаннага (чалавечага) ${ }^{5}$. Скрупулёзна даследаваўшы азёры Паўночнай Беларусі, вядомыя ў народнай традыцы пад назвай “святыя”, а таксама водныя аб'екты, з якімі звязаныя паданні пра патанулы храм, У. Лобач заключыў, што каниэнтрачьля аб'ектай сакральнай геаграфіі вакол некаторых святых азёр настолькі высокая, што дазваляе меркавачь пра надзвычайнь, культавы статус гэтых аб'ектаў $i$ ў часы да прынячия хрысиіянства ${ }^{6}$. Даследчык слушна ўказаў на тое, што ў вызначэнні месца тэафаніі чалавек дахрысціянскай эпохі натуральным чынам звяртаў увагу на круглае ў плане і невялікае (форма круга прасочваецца візуальна) азяро, якое $\ddot{y}$ міфа-

\footnotetext{
4 У. А. Лобач, Сакральная геаграфія беларускага Падзвіння, (у:) Палявая фалькларыстыка і этналогія: даследаванне лакальньхх культур Беларусі, Мінск 2008, с. 110-116; У. А. Лобач, Свет людзей $i$ свет багой: прастора й міфапаэтычнай кариіне свету беларусай, "Беларускі гістарычны часопіс" 2009, " 3, с. 12-17; інш.

5 У. А. Лобач, Сакральная геаграфія..., с. 110.

6 Тамсама, с. 114.
} 
паэтычнай традыцыі ўспрымалася як "вока", "акно" з таго свету і канал камунікацыі з ім7. Грунтойныя назіранні У. Лобача адносна семантыкі і рытуальнай функцыянальнасці базавых элементаў традыцыйнага культурнага ландшафту беларусай (у тым ліку балота, возера, ракі, крыніцы) абагульнены ў манаграфіi "Міф. Прастора. Чалавек: традыцыйны культурны ландшафт беларусаў у семіятычнай перспектыве" (Мінск, 2013). Культавыя вадаёмы Беларусі як асобыя экасістэмы і адмысловыя духойныя асяродкі разгледжаны ў працах Э. Зайкойскага і Л. Дучыц ${ }^{8}$.

"Філалагічны" бок сімволікі прыродна-ландшафтных, у тым ліку гідралагічных, вобразаў у сувязі з вывучэннем беларускай лірыкі і яе паэтыкі закранаўся Н. Гілевічам у даследаванні "Паэтыка беларускай народнай лірыкі. Слова і вобраз", А. Гурскім у манаграфіi "Пазаабрадавая лірыка ўсходніх славян", А. Лісам у працах, прысвечаных паэзіі народнага календара, і некаторымі іншымі вучонымі. Асаблівасці выяўлення прасторы сродкамі беларускай парэміялогіi, у якой сістэма семантычных каардынат міФа пра касмагонію і ўпарадкаванне свету захоўвае сваю актуальнасиь, вывучаліся Т. Валодзінай. Даследчыца, сярод іншага, засяродзіла ўвагу на функцыянальнасці вобразаў беларускага ландшафту (сярод якіх рака, возера, балота) у парэміялагічных тэкстах і выказала меркаванне, што для гэтых локусаў ужо не характэрнь прьищьл укладання, прастора па-за вёскай складаециа з райнапрайных элементай9.

Генезіс і сімволіку фальклорнага вобраза Дуная на песенным матэрыяле беларускай і іншых славянскіх традыцый на высокім навуковым узройні ўсебакова раскрыла Л. Салавей ${ }^{10}$. Даследчыца на прэзентатыўным матэрыяле здолела давесці, што вобраз Дуная, апавіты комплексам міфалагічных уяўлення ў, нясе ў сабе рысы "свяшчэннай ракі". Менавіта ўсведамленне сакральнасці Дуная, важнасці ўсіх уяўленняў, звязаных з ім, абумовіла тое, што нават у творы народнай лірыкі, пазбаўленыя міфалагічнага напайнення, шырока ўключаецца гэты вобраз, які набыў якасці эстэтычнага стэрэатыпа, а ў больш позніх паводле паходжання творах (казацкіх, салдацкіх песнях) ён мае пейзаж-

7 Тамсама, с. 115.

8 Э. М. Зайкойскі, Л. У. Дучыц, Жъьватворньля крынічы Беларусі, Мінск 2001.

9 Т. В. Валодзіна, Прастора $і$ час сродкамі парэміялогіi, (у:) Мальяя жанрьи. Дзічячы фальклор, Мінск 2004, с. 38.

10 Л. М. Салавей, Вытокі песеннай вобразнасиі фальклору ўсходніх славян, (у:) Узроўні агульнасиі фальклору ўсходніх славян, Мінск 1993, с. 24-137. 
на-геаграфічныя рысы і звязваецца 3 адносна нядаўнімі гістарычнымі падзеямі. Дунай як "міфічна-гістарычная прарадзіма славян", родавая рака-мяжа беларускага фальклору разглядаўся і А. Ненадаўцом. Прадметам даследавання гэтага вучонага сталі таксама міфалагічныя учяўленні пра некаторыя іншыя прыродна-ландшафтныя аб'екты і стыхіi, “жывую" і "мёртвую" ваду. Так, у раздзеле "Міфалогія" калектыўнай манаграфіi11 разгледжаны некаторыя пытанні міфалагічнага касмагенезу, міфалагізацыі воднай стыхіі, водная прастора (рака, мора) апісана як абмежавальнік родавых зямель. (Больш падрабязны разгляд гісторыі і вынікаў даследавання пэўных чыннікаў гідралагічнага кода беларускага фальклору гл. у прысвечаных ім артыкулах $\left.{ }^{12}\right)$.

У пэўным сэнсе фундаментам, на якім базіруюцца даследаванні розных кодаў (у тым ліку гідралагічнага) беларускага фальклору, з'яўляюцца грунтоўныя работы калектыву вучоных, створанага акадэмікам М. Талстым. Практычным увасабленнем ідэй М. Талстога і яго калег стаў выхад этналінгвістычнага слойніка "Славянские древности" (Масква, 1995-2014, т. 1-5), які з'яўляецца слоўнікам-указальнікам 3 тлумачальна-функцыянальнымі элементамі і мае надзвычай вялікую агульнагуманітарную каштойнасць. Яго аб’ект - гэта "мова" культуры (у семіятычным сэнсе), а вылучаныя у асобныя артыкулы адзінкі (сімвалы) - "словы" гэтай мовы. Шэраг артыкулаў, уключаных у слойнік (у прыватнасці, Т. Агапкінай, М. Валенцовай, Л. Вінаградавай, А. Леўкіеўскай, М. Талстога і інш.), прысвечаны апісанню асобных гідрааб'ектаў у адзінстве іх "рэальнай” формы і сімвалічнага зместу, што цалкам адпавядае таму важнаму месцу, якое займаюць гэтыя аб'екты ў традыцыйнай культуры славян (ды іншых народаў). Так, Л. Вінаградава ў слоўнікавым артыкуле ${ }^{13}$, прысвечаным апісанню сімвалічнага зместу ракі ў традыцыйнай мадэлі свету славян, разгледзе-

11 Міфалогія. Духойныя вершы. Беларускі фальклор. ЖКанры, віды, паэтыка: у 6 кн., кн. 5: Міфалогія. Духойньия вершы, пад. рэд. А. С. Фядосіка, Мінск 2003, с. 120-182.

12 І. А. Швед, Сімволіка балота ў міфапаэтьчнай кариіне свету беларусаў, "Весці НАН Беларусі. Сер. гуманіт. навук” 2009, № 4, с. 89-97; I. А. Швед, Сімволіка крынічы ў беларускім песенныл фальклоры, "Веснік Брэсцкага ӱніверсітэта. Сер. 3. Філалогія. Педагогка. Псіхалогія" 2011, № 1, с. 46-54; І. А. Швед, Мора як элемент касмалагічнага кода беларускага фальклору, "Весці БДПУ. Сер. 1. Педагогіка. Псіхалогія. Філалогія" 2012, № 2, с. 82-87; И. А. Швед, "Мифологическая этиология" водньи источников: белорусско-русско-польские параллели, "PAX SONORIS. Научный журнал", вып. VII, Астрахань 2013, с. 136-148; інш.

13 Славянские древности. Этнолингвистический словарь: в 5 т., Москва 2009, т. 4: П (Переправа через воду) - С (Сито), с. 416-419. 
ла некаторыя аспекты культурнай семантыкі гэтага гідрааб'екта, якія вызначаюцца такімі яго ўласцівасцямі, як хуткае цячэнне, рухомасць, працягласць у прасторы, звілістасць (крывізна русла). Рака сімвалізуе рух, шлях, дарогу ў іншасвет. Паказана, што у традыцыях розных славянскіх народаў рака функцыянуе як мяжа, небяспечны дэманічны локус, а ледаход і ледастаў інтэрпрэтуюцца народнай свядомасцю як сезонныя межы. Адзначым, што такія працы з'яўляюцца ў пэўнай ступені уззорам, складаюць корпус сістэматызаванага паводле адпаведнай схемы матэрыялу, важнага для даследавання гідралагічнага кода міфапаэтычных мадэляў свету розных традыцый. Але з прычын асаблівасці агульнай канцэпцыі і натуральнага абмежавання аб’ёму слоўніка (адпаведных артыкулаў) фальклорныя крыніцы (пераважна абрадавы фальклор і тэксты малых жанрай) выкарыстойваюцца ў ім толькі ў той ступені, у якой гэта неабходна для характарыстыкі абрадавага і міфалагічнага кола фактаў, а беларускія вуснапаэтычныя творы і ў гэтым кантэкце сустракаюцца эпізадычна.

Плёнам даследчыцкай працы айчынных фалькларыстаў, этнолагай, культуролагай, гісторыкай, археолагай, філосафаў стаў выхад энцыклапедычнага слойніка "Міфалогія беларусай", большасць артыкулаў якога выканана ў семіялагічным ключы. Натуральна, асэнсаванне традыцыйнага космасу беларусай уключае даследаванне гідралагічных сімвалай. Шэраг артыкулай, прысвечаных разгляданай праблеме, у прыватнасці "Мора"14, напісаны аўтарам гэтай работы. Некаторыя міфалагічныя ўяўленні беларусаў пра раку ў супастаўленні з старажытнаіндыйскімі апісаны ў артыкуле "Рака" названага слоўніка ${ }^{15}$. Яго аўтары - Л. Дучыц і У. Лобач - раскрылі пэўныя аспекты функцыянавання вобраза ракі ӱ касмаганічных легендах, у легендарнай гісторыі, абазначылі ролю ракі ̈̈ шэрагу магічных практык, а таксама ўказалі на культавае значэнне больш за 70 рэк Беларусі. Гэтыя ж аўтары прывялі міфалагічныя ўяўленні беларусай пра возера як "прыродны вадаём у паглыбленні зямной паверхні, суаднесены... 3 ніжнім ярусам светабудовы і падземнымі водамі" 16. У названым слойніку Л. Дучыц, У. Лобач, С. Санько ахарактарарызавалі калодзеж як адзін з дзейсньх каналаў камунікаџьі з іншасветам, иесна звязань

14 Міфалогія беларусаў. Энцыклапедычны слоўнік, Мінск 2011, с. 311-313.

15 Л. Дучыц, У. Лобач, Рака, (у:) Міфалогія беларусаў. Эниыклапедычны слоўнік, Мінск 2011, с. 398-400.

16 міфалогія беларусаў, с. 86-87. 
з жаночай сімволікай $i$ стыхіяй (зямной $i$ нябеснай) вільгачі17. Калодзеж у абрадзе выклікання дажджу стай прадметам даследавання С. Талстой і М. Талстога ${ }^{18}$.

\section{Мора (акіян), рака, возера, балота, калодзеж, крыніца як чыннікі гідралагінага кода}

Праведзены намі на матэрыяле розных жанраў беларускага фальклору сістэмны аналіз такога чынніка гідралагічнага кода, як мора (вар. мора-акіян $)^{19}$, дазваляе сцвярджаць, што у з залежнасці ад кантэксту, мора - пачатак і канец існага, з аднаго боку, - універсальны вобраз першапачатковага стану свету, увасабленне першаснай і вечнай стыхіі, жыццёвай субстанцыі, зыходная форма касмагенезу, а з іншага - мора судачыняецца з сферай смерці, сімвалізуе небяспеку, надзелена медыятыўным значэннем. Гэтыя міфалагічныя сэнсы вобраз мора захоўвае і ў паэтычных жанрах, прыкладам у сёмушнай песні з матывам смерці-шлюбу, дзе мора і Дунай выступаюць кантэкстуальнымі сінонімамі: Ходыла Наденька по новыл горідиу, // Купала градочкі, сіяла руточку. // Ставші, посіявші, стала польвватьл, // Ставші, польввавші, сіла спучьвватьы. // Сівші, спучівші, стала, нашчьтала, // Ставші, нашчытавші, у выночок звыла, // У выночок звыла, на Дунай пустылла. // - Хто выночка споймэ, то той мэнэ вузьмэ. // Хвалььвся хвалько - молодьг Іванко: // - Я вьночка спойму, я Надечку вузьму. // Як ступьв ногою - по пояс водою, // Як ступьгв другою - на дно головою. // - Бэжы тыл, коню, сыцдом додому, // Нbl кажы ты, коню, шо я ўтопьвся, // A скажь тыл, коню, шо я ўжэньвся, // Взяв собі жіночку - у моры шчучочку, // Взяв собі музыку - рыбу бэз'языку, // A моі гостонькы - у моры рыбонькы (Плоска Брэсцкага р-на). Мора у міфапаэтычнай карціне свету беларусай - сімвал бязмежнасці, невядомасці, цудоўнасці, далёкага, чужога свету, а таксама мяжа паміж чалавечым і тым светам. У апошнім выпадку мора асацыюецца $з$ полем, як у масленічнай песні: Цераз поле шырокае, // Цераз морэ гльюокае // Там ляжала гібка кладка, // Тудэю ішла Божа матка. // Нясла ключь пякельньяя // Пякельнічу адмыкачі, // Грэшны душы выпускачі

17 Тамсама, с. 213.

18 С. М. Толстая, Н. И. Толстой, Вызывание дождя в Полесье, (в:) Очерки славянского язычества, Москва 2003, с. 89-125.

19 І. А. Швед, Мора як элемент..., с. 82-87. 
(Дзяніскавічы Ганцавіцкага р-на). Мора таксама - локус прабывання персанажаў нячыстай сілы, жывёл, людзей-маргіналаў, ліміналаў ды цудоўных рэалій, сакральных памочнікаў героя.

$\boldsymbol{P a \kappa a}$, як паказала даследаванне розных відаў і жанраў беларускага фальклору ${ }^{20},-$ вынік дзейнасці сакральных персанажаў рознай прыроды, у калядных, валачобных песнях “быстрыя, беражыстыя" рэкі выцякаюць з слёз самога Бога ці птушак (напр., салаўя), звязаных з сферай sacrum; у чарадзейных казках рэкі разам з равамі, сценамі і да т. п. узнікаюць як перашкоды для пераследавацеляў з кінутых героем прадметаў накшталт стужкі, ручніка, шчоткі. Вытокі рэк могуць бачыцца як у ніжняй, так і верхняй сферах светабудовы, а самі рэкі маюць праекцыю як у макра-, так і мікрасвет, аж да чалавечага арганізму, як у замове “ад раны": Шла Божая маты, дэ тры річкы тэчэ: одна водяная, друга - мэдовая, а трэтяя - кровяная. Водяную $i$ мэдовую вып'ю, а кровяная - сі своім духом втомлюю (Гвозніца Маларыцкага р-на $\left.{ }^{21}\right)$. Часта рака маркіруе мяжу паміж рознымі сферамі светабудовы ці яе Цэнтр альбо выступае дарогай у іншасвет, акаляе яго ці з'яўляецца ім самім (паводле абміранняў, на тым свеце скупыя людзі з галавой знаходзяцца ў рацэ, але ўвесь час просяць піць), рэчышча Сусветнай ракі можа супадаць як з гарызантальнай, так і вертыкальнай восямі Сусвету. У песнях рака аддзяляе родную старану маладой жанчыны ад мужавай хаты, дзявочае жыццё ад жаночага (гл. частотны матыў "шырока рака, я не перайду"). Пераход праз раку абазначае эратычныя адносіны, заключэнне шлюбу, пры гэтым арганізойваць пераправу можа сакральны памочнік жаніха (голуб, змяя). У вясельных песнях хуткаплынная рака разам з іншымі прыродна-ландшафтнымі аб'ектамі аддзяляе бацькоўскую хату нявесты (яе дзявочы стан) ад храма, дзе бярэцца шлюб, адбываецца вянчанне, пераход у іншы статус: Bimэ конэйкь-воронці, // Чbl густыля по собі. // Чы довызэтэ княгыну // За тыі горы крутыі, // За тыі

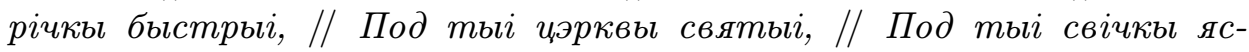
нылі, на тылі і рушнычкы більі (Гвозніца Маларыцкага р-на). Рака месца спатканняў, расставанняў герояў, локус дэманаў, зачараванага жаніха, метамарфоз чалавека, аб'ект праклёну, злога чаравання, у вы-

20 І. Швед, Рака, (у:) Беларускі Фальклор. Энцыклапедыл: у 2 т., т. 2, Мінск 2006, c. $427-428$.

21 Прыведзеныя $\ddot{y}$ працы фальклорныя матэрыялы захоўваюцца ў фальклорна-этнаграфічным архіве вучэбнай фальклорна-краязнаўчай лабараторыі БрДУ імя А. С. Пушкіна (кіраўнік - I. А. Швед). 
ніку чаго рака можа ператварыцца у б балота, праваліцца пад зямлю і г.д. Часта рака выяўляецца як месца смерці чалавека, патаплення, і гэта нярэдка становіцца сюжэтам тапанімічнага падання, прыкладам: Раскажьице адкуль пайшла назва вёскі вашай, чаму называеииа Скрыгалай? - Раскажу... Скрыгалаў назвалі ад слой “скрытая галава". Раньше тут бачюшка службу вёу - ачеи Макарый. Харошы баиюшка. За людзей сільна перажываў, за чэркву. А напалі на цэркву татары $і$ хачелі спалічь. Ачеи Макарый выйшаў первы да ворагаў, штоб людзі схавачиа ўспелі. Ну яны яму $і$ атрубілі голаву. Атрубілі $i$ ў рэчку кінулі. А ў рэчкі сразу галава і скрыласа. Вот адсюль i дзярэўню нашу назвалі "Скрыгалаў" - "скрытая галава". Но на саракавы дзень успльла галава і людзі вылавілі яе. А яшчэ я не сказала, што пахавалі бачюшка на берагу рэчкі Пячелічьл. Ну то калі галава ўспльла, то $i$ яе закапалі да мошчаў бачюшкі. А на тым месце паставілі стоўб, памятнік такі вылскі, ён і счас там стаічь. Кажды год - 14 мая ў нас у иэркві служаць. Прыязжаюиь папье $i$ сначала на Пячелічь служачь, а патом у иэркві. Я тожэ хадзіла ў иэркву, а счас уже сілы нема (Скрыгалаў Мазырскага р-на). Часта патапленне чалавека ў рацэ трактуецца як наканаванае лёсам, прыкладам: Як дылты ходят, ідуm под рәку $і$ будут бігаты, ходытыл. I пося крічат: "Ну, што, пошлітэ, діткі разом". Усі підуть. Одно: "Не, я нэ піду" I останэичя. I втопічия. Так, мусыть, назначано (Бучамля Камянецкага р-на).

Рака сімвалізуе чалавечую экзістэнцыю, змены, цячэнне часу, вечнасць і забыццё; як цякучая вада трактуецца у якасці і дабратворнай, ачышчальнай, і згубнай; з'яўляецца аб'ектам шанавання і месцам здзяйснення абрадай рознай скіраванасці. Рака, якая раздзяляе герояў песень, сімвалізуе сварку, разлуку. Вобраз ракі з чорнай вадой актуалізуецца і у замове "Если дучка забула матэра": B річкы чорнэі вода, в воді жовтыі бэрэга, а в хате моеі порогы, ходылль 6 ногы дочкь моеі до мэнэ, Божеі рабе (імя). Мэнэ б дочка уважала, стару мать ны забувала, як хвороба - нэ кыцдала, як я про еі трывожьллась: як кобыла трывожыция по своему жэрэбиыку, овия по своему ягнетку, гобка по своему гнездечку, а дочка моя по своему крылечку $і$ по мні Божеі рабі (імя). Амінь (Яблачнае Маларыцкага р-на). У песнях адносна позняга паходжання, прыпеўках вобраз ракі фармалізуецца, хоць нярэдка захойваецца яго лакатыўная функцыянальнасць, у прыватнасці як месца любоўных спатканняў ( $Я$ з міленькім сідела // У рекі под мостіком, // Он ушёл, а я сказала: // - Ть мартышка з хвостікам" - Рамель Столінскага р-на), смерці чалавека ці мяжы паміж 
сваім і чужым светам: $A$ з нэба упала пороша, // $A$ дід бабу полюбыу, бо баба хороша: // I сльппая, i крыввая, $i$ к тому ж злая. // A дэ дід повэрнэ, но баба всё кльинэ. // - Убырайся, бабка, у новэ одінне, // Мыь поідэм за рыку з тобою на высілле, // Убыралася, бабка, у новэ одінне, // Дэлю, дэлю, ідэм на выссілле. // Як ступьла бабка в воду ногою, // Iі дід попьхнув на дно з головою. // - О тут, бабо, кайся, о тут покупайся, // $A$ я пойду ожынюся, а ты оставайся... (Астромічы Кобрынскага р-на). Злучэнне некалькіх рэк у адну сімвалізуе аб'яданне людзей, у вясельных песнях - маладых, iх родаў: Сэй посажэ благословы Божэ... // Ой стыклося да дві річынькьи, // Дай обідвы быстрынькыи, // З'іхальсся дві посажынькы, // Дай обідвы молодэнькьь. // Пэршы посаг - з-под місяча, // Другы посаг - з-под соныйка. // Молоды Іванко - з-под місяча, // Молодая Ганночка - з-под соныйка. // Шио ж-то ў нэбы зазвьніло? // Сам Господь-Бог на высілле ідэ (Снітава Іванаўскага р-на).

Хоць Беларусь - “краіна азёраў”, возера ${ }^{22}$ не з'яўляецца частотным вобразам беларускага фальклору, практычна не прадстаўленае ў парэміялагічным фондзе. Найбольш часта яно згадваецца ў няказкавай прозе. Узнікненне азёраў, як і рэк, крыніц, у народных уяўленнях беларусаў звязана $з$ міфалагічнымі часамі першастварэння (сярод дэміургаў этыялагічныя легенды называюць Бога, старажытных волатаў, птушак). Этыялагічныя легенды пра канкрэтныя азёры нярэдка рэалізуюць матыў правалішча (горада, вёскі, храма, званой) як пакарання людзей за грэх, парушэнне традыцыйных правілаў, забарон. Гэтыя сюжэты звязаны з міфалагічнымі ўяўленнямі пра водны хаос, перамогу стыхій і сусветны патоп, які насылаецца на зямлю за грахі людзей, парушэнне імі парадку Натуры, Жыцця. Возера ў такіх кантэкстах прэзентуе касмічны ніз (азёры могуць лічыцца бяздоннымі, звязанымі з сусветным акіянам; гл. міфапаэтычную трактоўку возера як "вока", "акна" з таго свету, а таксама характарыстыку возера як вельмі глыбокага). Частотным матывам твораў няказкавай прозы выступае патапленне ў возеры. Прыкладам, пра возера каля в. Гарадная Столінскага раёна апавядаюць, што калісьці ӱ вёску прыйшлі татары разам 3 шведамі і пачалі здзекавацца з княжаскай сям'і. А калі яны сабраліся патапіць у возеры дачку князя, яе рагневаная маці вырвала з свёй галавы косы і кінула іх татарам у вочы, праклінаючы: Больш

22 Падрабязней гл.: Л. Дучыц, У. Лобач, Возера, (у:) МіФалогія беларусаў. Энцьклапедычны слоўнік, Мінск 2011, с. 86-87. 
не будзеш мечь ты поспеху! 3 тых часой $i$ гаворачь, што жанчына спасла Гарадную, таму што пасля гэтага швед не меў поспеху. Справа дайшла да таго, што пад Палтавай Пётр 1 разбіў яго начыста (хутар Замкавішча, в. Гарадная Столінскага р-на).

Гвалтойная смерць, патапленне чалавека (часта ў юнацкім узросце) у возеры трактуецца як прычына ператварэння возера ў балота (гэта ж характэрна і для трактойкі зарастання рэк) і пазней - і у поле. Утвораны локус, згодна міфапаэтычнай логіцы, становіцца прытулкам для нячыстай сілы, чарцей, прыкладам: Кольсь за Домачыєвом жылы на колоніі голэндры. Добрэ жыльи, бо добрэ робыльь. Зімля - вона завшы так: кто на йій працюйе - той ныколь ні горуйе. А тількі в одного тэго голэндра така біда прыключьллася. Був у його конь любимэй, шо він на йім тількі іздыьв, а ньи пахав ныколье. А тэй конь був такэй гарачьй, брыклівэй, шо ныла шо казаты. I був у того господара сын малэй, шо любыв на тэім коні кататыся. Батько йому нь дозволяв йіздыть, а він ньл слухався. А було там шиэ такэ возіро, шо бырыжкэ в його буль высокэ, $і$ воно було як бы в ямщэ. I йедного разу тэй хлопеи поіхав на тьлм коні коло того возіра. А тэй конь дурнэй як понес, шо ныла шо казаты. I хлопеи не встрылався $і$ скатьвся в тую ямку. А малэй шчэ був, $і$ втопьвся собі. Тодьи батько погорував, а потом взів застрэлів того коня, посік його, вкінув до тэі ямкі. I вжэ ны ловыльи там рыбы ныколы, а воно було богатое на рыбу, заросло воно, і кажуть, шо там сталы водытыся чэрты. I якось воно засмэрдэло з того часу, ну $i$ сталь называты його Дохлой Ямкэй. A як вжэ прыийль тэі мэліораторы, запахальи там все, $і$ стала там полэ. I вжэ ныхто ны помныть, дэ була тая Дохлая Ямка (Чэрск Брэсцкага р-на). Возера можа знікнуць у выніку магічных актаў (кіданне у яго патэльні, замка), чарадзейства-помсты за патапленне ў яго водах любімага чалавека, часта дзіцяці. На месцы возера, якое знікла у падземным свеце $\ddot{y}$ выніку праклёну, можа застацца толькі камень (відавочна, ён перашкаджае вадзе выйсці на паверхню зямлі). Так, апавядалі, што пад вялікім каменем, які ляжыць недалёка ад дарогі на Ваўкавыск, схавана зачараванае возера. Вельмі даўно нейкая пані хацела выкупаць свайго любімага сабаку, але ён ўтапіўся. ЖКанчына у гневе пракляла возера, і яно пайшло пад зямлю23. Паводле некаторых легендай, возеру, ператворанаму (заклятаму) у балота, можна вярнуць былы выгляд, выканаўшы цяжкае заданне: Няхай знойдзеица дзяиіна

23 Легенды і паданні, склад. М. Я. Грынблат, А. І. Гурскі, Мінск 2005, с. 370. 
сямі год, праедзе па балоту на кабыле трох год $і$ адиукае тое месца, дзе патануў сын [жанчыны, якая пракляла возера. - І.ШІ.]. На месиы тылм выраслі тры чараціны (тры кусты чароту), трэба іх таму дзяиіне вырвачь $i$, не азіраючьсся, увезиі прэч 24.

Святыя азёры ўспрымаюцца як месцы тэафаніi, сувязныя звёны з іншасветам, локусы-праваднікі, з дапамогай якіх здзяйсняюцца кантакты з прадстайнікамі sacrum і выдаленне з чалавечага свету "нячыстага" $\ddot{y}$ разнастайных яго праявах. Возера як канал камунікацыі з іншым, чужым, светам, асяроддзе зараджэння/з'яўлення чалавечага жыцця трактуецца у палескіх формулах пра паходжанне дзяцей (у такіх выпадках возера можа замяняцца ракой, ручаём, выступаць іх кантэкстуальным сінонімам). Возера - месца выканання розных рытуалаў, адпраўлення каляндарных абрадаў, у прыватнасці купальскіх: ...було вэльмэ вэсэло, гучно. Збіральи кветкі, плялі вяночкі, пелі песні. Пераапраналіся ў чорта, дзеда і іншых. Ужо пасля Купалля нельга було робыты шчо-нэбудзь на агародзе. Усё трэбо було зробыты до Купалля. У гэтую ноч расцвятала папараџь. Той, хто яе знойдзе, будэиь богатыл, здоровы $і$ шчаслівы. Запальвалі вогнішча. Хлопцы прыгалі праз яго. Потыцм усе купаліся уั возеры иі уั рачиыл... У гэтую нічь збыралася вся нэчьлттая сыла, ведьмы, і робыла людям пакості (Вольна Баранавіцкага р-на). У аповедах пра святкаванне Масленіцы возера (ці рака) фігуруе як месца, дзе вечарам таемна рыхтуюць апару для рытуальнай ежы - бліноў: Самьі правільныі бліны бульи з грэчневыі мукыл. Бліны готовыльи тайно. Моглы выходытыь вэчором до озэра, річкэ $i$ готовыльь опару. А другая ныкуды ны ила, а готовыла в сэбэ на дворі со сніга, алэ шоб світів місяч. Дальшэ робылы тісто з мукы $і$ молока. Тісто накрыввль рушныком $і$ ставыльь там, дэ тэпло. Піч топьльи сухымы бэрозовымы дровамы. Пыєлы на пэтэльнях з чыцуну, маленькыі. Вэльмы чьистымы должны бульи бутьи пыттэльні. Іх ставылль на огонь, нагрыьвалье, посыпальь соллю $і$ потом стыраль латкою. А бліны потом ны ліпльь до дна. Пэтэльню мазальи салом. Готовы бліны ставылы в тэплэ місцэ, шоб булы тэплымыл. Була і спэиіальна пусуда - блынніча (Яблачнае Маларыцкага р-на).

Возера разам з іншымі прыродна-ландшафтнымі аб'ектамі ўтварае адзіны сімвалічны комплекс, пры дапамозе якога актуалізуецца ідэя мяжы (між тым і гэтым светамі). У песнях, прыпеўках возера звычайна фігуруе разам з такімі прыродна-ландшафтнымі вобразамі, як

24 Дрэва кахання: легенды, паданні, сказы, склад. і аўтар прадм. А. І. Гурскі, Мінск 1993, c. 172. 
камень (Да вылятала ластаўка.. // Cbи-пад сіняга возера... // Cbи-nад белага каменя...25), поле (Ой, у полі азерца, // Там плавала вядзерца...26), рака: Не забуду я рекі, // Не забуду озера, // Не забуду я молойчіка, // Шо зімой морозіла (Адрыжын Іванаўскага р-на). Возера (верагодна, вялікіх памераў) можа не адрознівацца ад мора: I да на моpbl, на морыь, // На сіненькім возерьь, // Два кані ваду пілі...). Гэтыя два гідрааб'екты ўступаюць у адносіны сінаніміі і надзяляюцца аднолькавай негатыўнай ацэнкай, калі актуалізуюць свае паглынальныя магчымасці і сімволіку транзіту нечага з свету людзей у падземны свет, як у галашэнні жонкі па мужу: Як я ияпер буду жыці, я бяздольная, я бязшчасная!.. А расступіся, сіняе возера! А залей мяне з дзеткамі мальмі! Між тым, возера, у адрозненне ад мора (далёкага, чужога, небяспечнага), у шэрагу кантэкстаў асацыюецца з сваім светам, абжытай прасторай, бацькойскай хатай і пазітыўна ацэньваецца. Рух вады з возера $\breve{y}$ мора, як мы ӱжо пісалі, абазначае пераход лімінальнай істоты (увасобленай ракой) з аднаго свету (статусу) у другі: Цячэ рэчка з возера ў мора, // Едзе дзевачка з роскашь ў гора. // Цячьи, рэчка, $i$ не супьиняйся, // Едзь, дзевачка, $і$ не азірайся ${ }^{27}$.

Прыкметы і ацэнка азёраў нярэдка выяўляюцца праз колеравы код (узгадаем сакральную вызначанасць шматлікіх азёраў з назвамі "Белае", "Чорнае", "Сіняе", "Чырвонае"). Пры намінацыі размешчаных паблізу адно ля другога азёраў можа актуалізавацца апазіцыя "белы / чорны”. Пры гэтым возера, названае Белым, звычайна мае станоўчую ацэнку, успрымаецца як добрае, чыстае, рыбнае: $A$ чаму ваша возера называециа Белае? - Назвали [озеро] николь старые. Белое назвали, бо тут очень харошая вода була, очень харошая, и она була, как вам назвать, типа тарелочкой, ну, примерно, метров сто - сто пидесят всяк о тако було, то мелко, мелко, мелко, мелко. Ну и на Белом озере построили Берёзовскую ГРЭС. Но оно, оно соединено с Чорным. Только Чорнэ, наверно, нижэ за Белое на семисят или, можэт, большэ, то там ещё из Чорного качають сюда воду, когда жара большая, нэ хватае водь в Белом озере. Но в этом году било Белое озеро расшырылы немного, узвели канал ещё вокруг, а там зара за станцыляю делають тую улучшытельную систему, станцыю нашу Берёзовскую

25 Паэзія беларускага земляробчага календара, уклад. А. С. Ліса, падр. народ. календара У. А. Васілевіча, Мінск 1992, с. 251.

26 Песні пра каханне, склад. І. К. Цішчанкі, С. Г. Нісневіч, Мінск 1978, с. 121.

27 Вяселле. Песні: у 6 кн., склад. Л. А. Малаш, З. Я. Мажэйка, Мінск 1986, кн. 5, c. 127 . 
ГРЭС будут росшырять, от то там зара делають улучшытельную систему, там болота булэ. То так названа. Но в нас ещё есть Споровское озеро (Нівы Бярозаўскага р-на). Ацэнка азёраў у сувязі з колькасцю у іх рыбы выяўляецца у шматлікіх фальклорных кантэкстах, што можа станавіцца тэмай тапанімічных паданняў. Прыкладам, апавядаюць, што некалі сучасную частку Століна, ад будынка гарсавета да праваслаўнай царквы, займала вялікае возера. У гэтым возеры было злоўлена 100 (сто) лінёў. Адсюль і мястэчка атрымала назву Столін (Столін Брэсцкай вобл.).

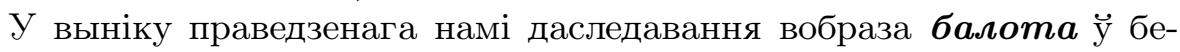
ларускім фальклоры ${ }^{28}$ высветлена, што тыповай і пераважнай аксіялагізацыяй балота, якое нясе семантыку смерці, ліха, з'яўляецца негатыўная (гэта абумойлена рэальнымі і прыпісанымі характарыстыкамі балота, яго міфалагічнай карэляцыяй з іншасветам і дэманічнымі істотамі, з хтанічным ярусам светабудовы, нізам, што, дарэчы, актуалізуецца у тэкстах фальклору адносна позняга паходжання, прыкладам вясельных прыпеўках: Я у болото ны пойду, // Бо воды боюся, // На грудочку постою // Дай додом вэрнуся (Стаўкі Бярозаўскага р-на). Між тым у беларускай фальклорнай традыцыі прысутнічае нямала сведчанняў таго, што балота судачыняецца 3 ідэяй жыццядайнасці і пазітыўна ацэненымі вобразамі. Ва ўсякім выпадку шэраг твораў указвае на тое, што балота з яго крэатыўнымі патэнцыямі магло мысліцца $\ddot{y}$ якасці першапачатковага стану сусвету і жыццёвай субстанцыі ці пазітыўнага элемента светабудовы. Сімвал балота выяўляе адмысловае адзінства процілегласцей: балота як хаос усё раскрывае, нараджае, і ў той жа час усё паглынае, усё нівеліруе, хавае ўнутр. Адносіны балота да светабудовы, такім чынам, дваістыя: і канструктыўныя, і дэструктыўныя.

Водныя крыніщы асэнсоўваюцца народнай свядомасцю беларусаў як адны з вызначальных чыннікаў светаўладкавання, як кропкі згушчэння прыродна-касмічнай, сакральнай і культурнай энергіi 29 . Таму лагічна, што з'яўленне крыніц узводзіцца да акту светастварэння дэміургам (часцей боскай прыроды). Акрамя касмаганічных матываў, сюжэты пра ўзнікненне крыніц (звычайна шанаваных у пэўнай мясцовасці) увабралі ў сябе шматлікія іншыя складнікі традыцыйнай духойнай культуры - уяўленні пра іерархічнасць, цэнтрыраванасць

28 І. А. Швед, Сімволіка балота.., с. 89-97.

29 И. А. Швед, “Мифологическая этиология" водных источников.., с. 136-148. 
і анізатропнаць (нераўназначнасць кірункаў) ландшафту, міфалогію жывёл, раслін, артэфактаў, субстанцый, канцэпты канфлікту, граху, выратавання, пакарання (згадаем матывы "правалішчаў"), побытавыя забароны, народныя культы святых і іншае. З'яўленне шанаванай крыніцы можа трактавацца як вынік і благаслаўлення, і гневу вышэйшых нябесных сілаў. У шматлікіх вуснапаэтычных творах, у першую чаргу песенных ${ }^{30}$, крыніца выконвае шэраг сімвалічных функцый, звязана з пэўнай групай персанажаў і дзеянняў. У пераважнай бальшыні песень крыніца - локус такіх персанажаў, як жанчына, дзяўчына, хлопец і яго конь, радзей - іншых жывёл. У калядках крыніца надзяляецца статусам святога месца, у якім знаходзяцца Божая Маці і Ісус Хрыстос. Гэты гідрааб'ект нярэдка выступае мэтай руху галоўнага персанажа песні, каля яго адбываюцца асноўныя падзеі твора. У абрадавых і пазаабрадавых песнях гэты вобраз сімвалічна звязаны з матывамі маладосці, прыгажосці, кахання, пачатку, сватання, вяселля, забеспячэння чаканых даброт, выступае ӱніверсальным знакам жыцця. У песнях на шлюбную тэматыку, як і у творах іншых жанраў фальклору, крыніца надзяляецца жаночай семантакай і выступае эротыка-сексуальным сімвалам. Сімвалічныя карціны купання ў крыніцы, яе капання маюць выразны любоўна-эратычны падтэкст. 3 крыніцай цесна звязаны матыў піцця. Згода дзяўчыны напаіць з крыніцы хлопца ці яго каня сімвалізуе прыняцце кахання, уступленне ӱ інтымныя стасункі. Пераважная пазітыўная ацэнка крыніцы, верагодна, матывавана яе асобай пазіцыяй у міфапаэтычнай карціне свету - як ідэальнай вады. Калі крыніца атрыбутуецца як бяздонная, ацэнка "добра/дрэнна" ў разгляданай апазіцыі поўнасцю інверсіруецца, што звязана з адмойнай аксіялагізацыяй бездані. Вынясенне крыніцы за межы сваёй прасторы, у чыстае поле, лес, падкрэслівае сімвалічную семантыку, якой валодае вада $\breve{y}$ народнай культуры ў цэлым. Яна выступае мяжой, якая аддзяляе замагільны свет ад свету людзей. Таму прасторавая схема, у якую змешчана крыніца, можа сімвалізаваць смерць персанажа. Функцыянаванне крыніцы як абагульненага знака суму абумоўлена яе асацыяцыяй 3 цякучымі слязамі і шырэй - міфалагічнай карэляцыяй воднай стыхіі з матывамі небяспекі і смерці. Што да эпітэта вады "крынічная" ў лірычных песнях, то ён, верагодна, па сваёй сутнасці выконвае функцыю ўпрыгожання, указвае пераважна на анталагічную ўласцівасць вады.

30 І. А. Швед, Сімволіка крыніць ў беларускім песенньм фальклоры,, "Веснік Брэсцкага ўніверсітэта. Сер. 3. Філалогія. Педагогка. Псіхалогія” 2011, № 1, с. 46-54. 
Тым не менш гэты эпітэт, надзелены ацэначнай функцыяй, здатны выяўляць істотныя асаблівасці беларускага песеннага ӱніверсуму, фарміраваць яго вобразныя і сюжэтныя абрысы.

Жаночую сімволіку, медыятыўную функцыянальнасць, міфалагічную далучанасць да іншасвету, зямной і нябеснай вільгаці падзяляе з крыніцай калодзеж, які часта трактуецца як аналаг прыроднай крыніцы і выступае месцам здзяйснення адпаведных абрадаў, у першую чаргу выклікання дажджу, матрыманіяльных варожбаў. Калодзеж, як і прыродная крыніца, можа звязвацца і з персанажамі хрысціянскага пантэону (Божая Маці, св. Параскева Пятніца), і з нячыстай сілай, чортам, дэманамі хвароб і інш., лічыцца шляхам у “вырай”, у прыватнасці для ластавак, якія на Уздзвіжанне апускаюцца на зімоўку на дно крыніц ці калодзежаў. Калодзеж як канал камунікацыі паміж зямной і падземнай сферамі светабудовы прадстаўлены ў розных жанрах - ад чарадзейных казак да аповедаў аб "праўдзівых" снах. Прыкладам жыхарка в. Ляплёўка Брэсцкага раёна апавядала нам: Мне самой снилось так о. Зашла там до одного (а у меня дети умирали очень. Сразу ничего, первое померло, второе при родах...). Ну и снится мне, што иду деревней, до одного соседа свернула в огород воды с колодиа вытянуть ведро. И тяну, тяну. Зачерпну с колодча, знаешь, как тянуть за тычку? Тылько шо зачэрпну, тылько надо хватить мни так о ведро поднять, вытащить, - оборвалось назад. Опять туда тяну. И што ты думаешь: сколько приснилося разов, што оборвалося ведро, пять, сем ведер. Вот тоби на. Двое похоронила, а пять було самопроизвольньх выкидышей. Тры месяиь дохожу, и оборвется. И о то так: тяну, тяну этое ведро, только хватать за этое ведро - оборвется назад в колодеч. Я сразу поняла. Сразу предупреждения. Як у крыніцу, балота, раку, так і $\ddot{y}$ калодзеж - праходы-шляхі $\ddot{y}$ іншасвет - кідаліся рытуальныя і іншыя прадметы, якія неабходна было выдаліць з чалавечага свету. Між тым вада з калодзежа лічылася гаючай, ачышчальнай. Калодзеж разам з іншымі прыродна-ландшафтнымі аб'ектамі згадваецца ў словах айцой царквы, скіраваных супроць язычніцкіх маленняў "бесам" каля калодзежаў, супроць пакланення калодзежам, рэкам, крыніцам, дрэвам і ахвяраванняў калодзежам, балотам і пад. Дарэчы, яшчэ данядаўна ў вясельнай абраднасці маладая, ідучы першы раз па ваду $\ddot{\mathrm{y}}$ сялібе мужа, павінна была пакінуць на калодзежы акрайчык хлеба, сыра ці грошы. У адрозненне ад прыроднай крыніцы калодзеж у якасці “рукатворнага" аб'екта ўлучаны у антрапагеннае асяроддзе, гаспадарчыя, "свае" пабудовы, якія адпаведным чынам закладваюцца, асвяшчаюцца, ахойваюцца. Пры заклад- 
цы калодзежай, як і іншых пабудой, прытрымліваліся прадпісанняў, звязаных з часам (шчаслівыя дні, малады месяц, раніца) і прасторай.

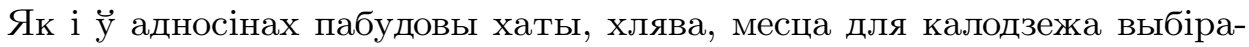
лася з улікам вынікаў варажбы, у прыватнасці па ступені вільготнасці пакінутай на ноч пражы ${ }^{31}$. У песенных тэкстах калодзежы разам з крыніцамі могуць утвараць сімвалічны комплекс, знаходжанне гэтых гідрааб'ектаў блізка ад хаты станоўча ацэньваецца. У песнях пра долю маладой замужніцы у мужавай хаце такая сімвалічная карціна ўказвае на выгоднае жыццё жанчыны, прыкладам: Догадалася маты, // Kyды дочку оддатьи: // Дэ сады зэленьее, // Дэ выєшни чэрвоныее, // Дэ колодьъі блізко, // Дэ ключі вісят нізко (Пешкі Бярозаўскага р-на).

Абагульняючы праведзеныя намі і іншымі вучонымі даследаванні чыннікаў гідралагічнага кода беларускага фальклору, з улікам вынікаў рэканструкцыі кодаў прыродна-ландшафтнага ${ }^{32}$ і дэндралагічнага (які перасякаецца 3 ландшафтным у сферы, звязанай з семіятызацыяй адзінока стаячых і растучых групамі дрэў, гаю, лесу, саду) $)^{33}$, можна выказаць некаторыя меркаванні адносна генезісу, семантыкі і функцыянальнасці гідралагічнага кода. У адносінах да вобразаў гідрааб'ектаў (як гэта было зроблена намі ў дачыненні дрэў${ }^{34}$ ) умоўна можна вылучыць "сакральна" і "прафанна" арыентаваныя версіі іx выявы у беларускім фальклоры. У першым выпадку гідравобраз рэпрэзентуе ўяўленні пра здольны да бясконцай рэгенерацыі Космас, выконвае медыятыўныя функцыі, з'яўляецца знакам сакральнай прасторы-часу - кадзіруе станоўча ацэнены цэнтр, верх (у першую чаргу гэта стасуецца ракі, яе вытокаў) ці выяўляе адмойна адзначаныя фрагменты светабудовы, ніз, перыферыю (найперш, возера і балота), а таксама этыялагічныя, генеалагічныя, аксіялагічныя структуры, рэпрэзентуе цесна звязаныя, узаемадапаўняльныя ӱ міфапаэтычным мысленні канцэпты нараджэння-тварэння, пладавітасці, вітальнай сілы, смерці-дэструкцыі і абнаўлення-адраджэння. У другім выпадку - найчасцей з'яўляецца спадарожнікам долі чалавека, вызначальнікам лёсу,

31 Падрабязней пра сімволіку і семантыку калодзежа ў беларускай традыцыі гл.: Л. Дучыц, У. Лобач, С. Санько, Калодзеж, (у:) Міфалогія беларусай, Мінск 2011, c. 213-214.

32 I. А. Швед, Усталяванне семантычных сувязей.., с. 75-76.

33 I. А. Швед, Дэндралагічны код беларускага традыцыйнага фальклору: дыс. на атрыманне вучонай ступені доктара філал. навук па спецыяльнасиі 10.01.09 фалькларыстыька, Мінск, 2007, с. 211-214.

34 Тамсама. 
перадае ўласцівасці псіхікі чалавека, яго настрой і пачуцці, а таксама выяўляе чалавека як істоту цялесную (гл., прыкладам жаночую сімволіку ракі, калодзежа, іх карэляцыю з саматычным кодам). Гідралагічны код у розных жанрах фальклору можа высвечваць наступныя аспекты макраполя "чалавек": знешні выгляд, полавую і ўзроставую прыналежнасць, тып паводзін і камунікатыўнай дзейнасці, міжасабовыя ўзаемадзеянні людзей, духойныя і разумовыя здольнасці, характар, сямейна-сацыяльнае становішча, эмоцыі лірычных герояў, у тым ліку звязаныя са зменай іх сямейна-сацыяльнага статусу і здзяйсненнем адпаведных рытуалай, абрадаў. У межах агульнафальклорнага "прынцыпу дыялагізму" як спосабу зносін з універсумам гідрааб'ект (нават у сваёй аб'ектыўна-прыроднай іпастасі) выступае як суб'ект, надзелены асобаснасцю. Дадзеная з'ява грунтуецца на міфапаэтычным узройні мыслення.

Усталёўваючы парадыгматычныя адносіны 3 сімваламі іншых кодаў, гідралагічныя сімвалы падпарадкойваюцца канкрэтным сінтагматычным адносінам i, у залежнасці ад кантэксту, здольны выяўляць амбівалентныя значэнні, звязвацца з сістэмай устойлівых касмічных, прыродных і метафізічных апазіцый. Адэкватная інтэрпрэтацыя гідралагічных сімвалаў у пэўных кантэкстах абумоўліваецца функцыянаваннем разам з імі прэдыкатай (з семантыкай актыўнага дзеяння ці знешняга ўздзеяння) і атрыбутай; неабходная ступень удакладнення семантыкі таго ці іншага сімвала дасягаецца спалучэннем гэтых характэрных знакай-спецыфікатарай. Апошнія, з аднаго боку, маюць замацаваную традыцыяй змястойнасць, а $з$ другога - у спалучэнні з пэўным гідрааб'ектам атрымліваюць адпаведны статус. Гідрааб'екты набываюць аксіялагічнае асэнсаванне $\ddot{y}$ адпаведнасці $з$ агульнай міфалогіяй прасторы $\breve{y}$ беларускай фальклорнай традыцыі, асноўныя адзінкі гідралагічнага кода надзяляюцца рознага кшталту ацэнкамі ў адпаведнасці з прыпісанымі ім семантычнымі прыкметамі. Асобыя адносіны звязваюць гідралагічны сімвал з прасторавым, персанажным, саматычным, субстантыўным, метэаралагічным, раслінным, колеравым, лічбавым і іншымі кодамі, акцэнтаванне і нюансіройка якіх у адносінах да гэтага сімвала ўздзейнічаюць на яго сэнсавую нагрузку і нават здольныя, згодна з патрабаваннямі паэтыкі, істотна мадыфікаваць гідралагічны сімвал, пераводзіць яго з класа элементаў, што адзначаюць "свой" свет, у разрад элементай-маркёрай "таго" свету з адпаведнымі наступствамі. Уключанасць усіх складнікай гідралагічнага кода $\breve{y}$ адзіную семіятычную прастору мадэлі свету, упарадкаванне (паводле прынцыпаў падабенства і сумежнасці) семантычных сувязяў 
гідралагічных сімвалаў, узаемаўзгодненае (на аснове рэалізацыі ідэі дапаўняльнасці) функцыянаванне гідралагічных сімвалаў з складнікамі іншых кодаў з'яўляюцца аснойнымі фактарамі ўстойлівасці гідралагічнага кода.

Асноўная характарыстыка структуравання комплексу міфапаэтычных уяўленняй пра гідрааб'екты - гэта іх сістэмная арганізацыя, якая хоць і мае свой унутраны сінтаксіс, але з'яўляецца адносна свабоднай і варыятыўнай. Сістэмнасць выяўляецца ў перапляценні роляў і функцый, агульнасці інфармацыйных зон, матываў у дачыненні да розных гідралагічных сімвалаў, што павялічвае інфармацыйную ёмістасць і гістарычную ўстойлівасць гідралагічнага кода. У любым гідралагічным сімвале (нават балоце) можна вызначыць патэнцыяльныя магчымасці актуалізацыі як пазітыўна-ўтваральных, так і негатыўна-дэструктыўных аспектаў быцця, што матывавана спецыфікай міфатворчых формаў свядомасці, а таксама асаблівасцямі прадстаўлення канцэптуальнай сферы традыцыйнай карціны свету $\ddot{y}$ фальклорных жанрах.

У заключэнне адзначым, што праз пасрэдніцтва гідралагічнага (шырэй - ландшафтнага) кода і сёння мадэліруюцца важныя фрагменты карціны свету, перадаецца значымая інфармацыя, звязаная з пэўнымі базавымі сэнсамі, здзяйсняецца рэтрансляцыя самой традыцыйнай і сучаснай культуры. Глыбокае вывучэнне гідралагічнага кода міфапаэтычнага мыслення беларусаў у пэўнай ступені спрыяе асэнсаванню народнай міфалогіi прасторы, логікі канструявання значных канцэптаў і вобразаў сродкамі розных кодаў, цэласнай тыпалогіi беларускага светаўспрымання і светаадлюстравання, усведамленню таго, што складае “духойны генатып" беларусаў i, магчыма, не будзе марным для актуалізаваных у апошні час пошукаў нацыянальнай ідэалогіi. У сувязі з гэтым згадаем заўвагу I. Чароты адносна аднаго з дамінатных элементаў гідралагічнага кода беларускай культуры - балота, якое, на думку вучонага, нясе $\ddot{\mathrm{y}}$ свядомасці ідэаграму “этнас у сусвеие". Гэта не толькі вылва, але і каларыт, і рытм, $і$ настрой, паводле якіх можна ідэнтыфікавачь дух насельнікаў увасобленай прасторы. I далей: (...) пайшойшы ад балотнага архетыпа, неабходна імкнучча да асэнсавання иэласнай тыпалогіi беларускага светаадлюстравання $(\ldots)^{35}$.

35 I. А. Чарота, Пошук спрадвечнай існасиі: Беларуская літаратура ХХ стагоддзя ў працэсах начьиянальнага самавызначэння, Мінск 1995, с. 107, 142. 
S T R E S Z C Z E N I E

\section{HYDROLOGICZNY KOD FOLKLORU BIAŁORUSKIEGO}

W artykule omówiono teoretyczne i metodologiczne podstawy badań kodu hydrologicznego, jego strukturę, parametry typologiczne, powiązania z kodami pokrewnymi - substancji, zjawisk naturalnych i innych. Zrekonstruowano semantykę i symbolikę podstawowych elementów kodu hydrologicznego - morza, rzeki, jeziora, bagna, źródła, studni.

Słowa kluczowe: kod hydrologiczny, symbol, obraz, system, klasyfikacja, folklor białoruski.

\section{S U M M A R Y}

\section{HYDROLOGICAL CODE OF THE BELARUSIAN FOLKLORE}

The article considers the theoretical and methodological bases of hydrological code research, its structural and typological parameters and links with related codes - substances, elements, natural phenomena, etc. There are also reconstructed semantics and symbolism of the main elements of the hydrological code - sea, river, lake, swamp, spring, well.

Key words: hydrological code, symbol, image, system, classification, Belarusian folklore. 